INTUISI 12 (1) (2020)
INTUISI
JURNAL PSIKOLOGI ILMIAH
http://journal.unnes.ac.id/nju/index.php/INTUISI
Terindeks DOAJ: 2541-2965

\title{
PENERAPAN MODEL PEMBELAJARAN PICTURE AND PICTURE BERBASIS KEANEKARAGAMAN HAYATI DALAM PEMBENTUKAN EMPATI ANAK USIA DINI
}

\author{
Henny Puji Astuti ${ }^{\bowtie}$, Agustinus Arum Eka Nugroho, Noer Azizah Rosita Dewi
}

Fakultas Ilmu Pendidikan, Universitas Negeri Semarang, Indonesia

\begin{tabular}{l}
\hline Info Artikel \\
\hline Sejarah Artikel: \\
Disubmit 26 Februari 2019 \\
Direvisi 21 Maret 2020 \\
Diterima 30 Maret 2020
\end{tabular}

Keywords:

Emphaty, Children,

Picture

\begin{abstract}
Abstrak
Data awal menunjukkan bahwa masih terdapat anak usia dini yang belum menunjukkan perilaku yang mengarah pada empati terhadap orang lain, sementara perilaku empati ini sangat penting untuk membina kehidupan sosial. Keberadaan binatang dan tumbuhan akan menjadi objek yang menyenangkan bagi anak sebagai pengenalan karakter dan penyampaian pesan. Anak tersebut meniru perilaku teman maupun perilaku yang sudah dibawa dari rumah. Salah satu upaya untuk mengembangkan kemampuan empati anak usia dini adalah melalui penerapan model pembelajaran picture and picture berbasis keanekaragaman hayati. Tujuan penelitian ini adalah untuk mendapatkan fakta dan menjelaskan tentang perbedaan kemampuan empati anak usia dini berdasarkan pada penerapan model pembelajaran picture and picture berbasis keanekaragaman hayati. Hipotesis dalam penelitian ini adalah terdapat perbedaan kemampuan empati pada 41 anak usia dini ditinjau dari penerapan model pembelajaran picture and picture berbasis keanekaragaman hayati. Subjek penelitian menggunakan anak usia dini di TKB. Teknik sampling menggunakan sampel jenuh. Metode pengumpulan data menggunakan Skala Empati Anak Usia Dini, serta analisis data menggunakan Independent Samples t-Test. Hasil dari penelitian ini adalah terdapat perbedaan kemampuan empati anak usia dini melalui penerapan model pembelajaran picture and picture berbasis keanekaragaman hayati, $\mathrm{t}=2,310$ dengan taraf signifikansi 0,026. Kemampuan empati anak usia dini kelompok eksperimen lebih tinggi daripada kelompok kontrol.
\end{abstract}

\begin{abstract}
Preliminary data showed that there are still young children who have not behaved that lead to empathy for others, while empathy behavior is very important to foster social relationships. The existence of animals and plants is a pleasant object for children and a means of character recognition and delivery of messages. Such as children imitate the behaviour of friends or behaviour that occurs at home. Efforts to improve children's application of picture and picture models. This study aims to prove and explain the differences in early childhood empathy abilities by using biodiversity based picture and picture learning model. The hypothesis of this study is that there is difference in early childhood empathy through biodiversity based picture and picture learning method. Research subjects used 41 early childhood from kindergarten group B. Sampling technique using saturated samples. The data collection method uses early childhood emphaty scales, while data analysis uses independent sample t-test. The result of the analysis showed that there was a difference in the ability of emphaty for early childhood through the application of a biodiversity picture and picture learning model, $t=2.310$, with a significance probability of 0.026. Emphaty ability of the early age experimental group was higher than the control group.
\end{abstract}

(C) 2020 Universitas Negeri Semarang

\footnotetext{
Alamat korespondensi:

Jurusan Psikologi, Fakultas Ilmu Pendidikan Universitas Negeri

p-ISSN 2086-0803

e-ISSN 2541-2965

Semarang, Kampus Sekaran, Gunungpati, Semarang Indonesia

hennypa@mail.unnes.ac.id
} 


\section{PENDAHULUAN}

Empati merupakan wujud dari kepedulian terhadap sesama. Terdapat banyak alasan untuk tanggap terhadap perasaan orang lain. Orang dewasa maupun anak usia dini dapat memiliki empati. Anak usia dini merupakan anak yang berusia 0-6 tahun (Astuti, 2013). Anak usia dini merupakan anak sejak lahir hingga berusia 6 tahun (Peraturan Menteri Pendidikan dan Kebudayaan RI No. 37 Tahun 2014 Tentang Standar Nasional Pendidikan Anak Usia Dini, 2014). Dalam usia ini, anak banyak membutuhkan pendampingan dari orangtua dan orang dewasa di sekitarnya. Pola perilaku yang terbentuk tidak lepas dari proses pembelajaran dari lingkungan. Empati merupakan suatu keterampilan yang dapat dipahami dan dipelajari anak. Anak mengamati perilaku tersebut dari orang dewasa maupun teman sebaya untuk dijadikan acuan dalam berperilaku di kemudian hari. Proses ini dapat tampak secara langsung maupun tidak.

Empati menjadi kajian yang tidak dapat terlepas dari anak usia dini. Empati selalu mengikuti segala aktivitas anak. Empati merupakan kemampuan untuk menangkap dan memaknai perasaan orang lain dengan berbagai masalahnya, berpikir dari pesepsi orang lain, serta menghargai berbagai jenis perasaan (Iis, 2012). Ketika anak memunculkan empati dalam dirinya, berarti anak mulai mampu memposisikan perasaannya pada perasaan orang lain. Perilaku yang muncul setelahnya adalah peduli. Empati disebut sebagai pemahaman persepsi yang mengacu pada respon emosi dan reaksi orang lain.

Aspek empati terdiri dari empati kognitif (pengambilan perspektif dan imajinasi) dan empati afektif (perhatian empatik dan distress pribadi) (Zoll \& Enz, 2012). Pada pengambilan perspektif (perspective taking), kemampuan spontan anak dalam berpikir berdasarkan sudut pandang orang lain merupakan bekal dalam memposisikan dirinya pada posisi orang lain. Kemampuan ini sangat dibutuhkan dalam hubu ngan sosial. Anak turut merasakan apa yang dirasakan temannya. Imajinasi (fantasy) merupakan aspek empati yang dominan. Kemampuan untuk seolah-olah mempunyai karakter yang dimiliki oleh tokoh pada buku maupun film. Imajinasi positif akan mengarahkan pada munculnya perilaku empati dan menolong. Buku bergambar dan film ini memiliki alur dan tema yang dapat diikuti. Aspek selanjutnya adalah perhatian empatik (empatic concern). Perasaan simpatik, belas kasihan, dan peduli pada orang lain menjadi bagian dari perhatian empatik. Perhatian empatik dapat dilihat secara gender. Anak berjenis kelamin perempuan memiliki kemampuan sosial dan prososial lebih tinggi dibanding anak laki-laki (Altay \& Gure, 2012). Anak perempuan mampu berbagi dan bekerjasama. Distress pribadi merupakan pembiaran terhadap ketidaknyamanan diri yang disebabkan oleh permasalahan orang lain. Hal ini dapat terwujud dalam bentuk ketakutan, kecemasan, kegelisahan, kecemasan, kebingungan, dan kuatir kalau tidak menolong.

Penulis mengumpulkan data awal di salah satu TK (Taman Kanak-kanak) di Gunungpati. Tampak anak yang masih asyik dengan dirinya tanpa peduli dengan teman sekitar. Terlihat anak mentertawakan temannya yang jatuh dan berdarah, hal ini dianggap sebagai lelucon. Dalam pembelajaran di kelas pun, beberapa anak enggan untuk meminjamkan alat tulis pada temannya. Guru kelas menceritakan bahwa pola perilaku anak sebagian besar dibawa dari rumah. Perkataan tidak pantas pun sering ditujukan pada temannya. Orangtua yang sibuk cenderung memanjakan anaknya dengan cara menuruti segala permintaan anak. Bahkan terdapat orangtua yang tidak terima ketika anaknya dikritik. Orangtua menilai bahwa anaknya adalah anak penurut yang 
tidak mungkin melakukan hal yang tidak diinginkan oleh orang lain. Kegiatan parenting belum dapat dilakukan secara berkala oleh pihak sekolah, sehingga jika terdapat masalah, biasanya diselesaikan sendiri oleh guru.

Penulis berharap anak usia dini memiliki rasa empati terhadap sesama. Empati ini akan menjadikan anak lebih peduli pada teman dan orang lain di sekitarnya. Empati merupakan suatu hal yang dapat dipelajari dan diterapkan oleh anak. Orang dewasa di sekitar anak diharapkan dapat memfasilitasi pengembangan empati ini. Penulis memilih picture and picture berbasis keanekaragaman hayati sebagai model pembelajaran. Anak akan menyukai kartu bergambar manusia, hewan, dan tumbuhan yang merupakan cerita seri. Anak diminta mengurutkan dan menceritakan apa yang tergambar dalam kartu tersebut. Kemudian peneliti mengajak diskusi tentang tema dalam cerita. Anak akan belajar hal baru tanpa merasa tertekan dan tersudut. Setelah mendapatkan data awal, penulis ingin mengetahui perbedaan empati anak usia dini berdasarkan pada penerapan media pembelajaran picture and picture berbasis keanekaragaman hayati. Jadi, terdapat kesenjangan antara harapan dan kenyataan secara nyata. Data awal menunjukkan bahwa anak usia dini di salah satu TK di Kecamatan Gunungpati belum memiliki tingkatan empati sesuai harapan penulis, yang mencakup empati kognitif (pengambilan perspektif dan imajinasi) dan empati afektif (perhatian empatik dan distress pribadi).

Pembelajaran merupakan suatu proses dalam pengenalan pengetahuan baru yang merupakan hasil interaksi dari beberapa pihak. Terdapat banyak model pembelajaran yang diterapkan di Indonesia. Penerapan model pembelajaran ini juga berlaku untuk anak usia dini. Model pembelajaran picture and picture dapat diterapkan bagi anak. Pemerolehan pengetahuan dalam lingkungan informal sangat menguntungkan untuk menarik minat dan perhatian anak, misalnya mengunjungi kebun binatang (Yamahashi, et al., 2015). Selain itu, binatang juga dapat diperkenalkan melalui cerita bergambar. Model pembelajaran ini bersifat aktif dengan menggunakan gambar berpasangan maupun berurutan. Contohnya menyusun gambar berurutan, menunjukkan gambar, memberi keterangan gambar, dan menjelaskan gambar. Gambar yang dipakai dapat berupa keanekaragaman hayati. Hal ini dimaksudkan agar anak dapat mengembangkan empati dalam kemasan keanekaragaman hayati. Cinta terhadap lingkungan juga harus ditumbuhkan sejak dini.

Tujuan penelitian ini adalah untuk mendapatkan fakta dan menjelaskan tentang perbedaan kemampuan empati anak usia dini kelompok eksperimen dan kelompok kontrol berdasarkan pada penerapan model pembelajaran picture and picture berbasis keanekaragaman hayati. Manfaat penelitian ini adalah untuk mendapatkan masukan secara empiris tentang perbedaan kemampuan empati anak usia dini berdasarkan pada penerapan metode picture and picture, sehingga dipakai sebagai dasar pemberian perlakuan dalam situasi pembelajaran di sekolah. Hipotesis yang diajukan adalah terdapat perbedaan empati anak usia dini kelompok eksperimen dan kelompok kontrol berdasarkan pada penerapan model pembelajaran picture and picture berbasis keanekaragaman hayati.

\section{METODE}

Populasi merupakan wilayah generalisasi untuk diselidiki, dibatasi sebagai bagian yang setidaknya mempunyai satu sifat yang sama untuk dapat disimpulkan (Sudaryono, 2017). Populasi penelitian ini adalah anak kelompok TK B di salah satu TK di Gunungpati. Populasi berjumlah 41 anak. Sampel merupakan bagian dari populasi yang memiliki ciri-ciri sama. Sampel dalam penelitian ini adalah bagian dari populasi, yaitu anak kelompok TK B berjumlah 41 anak. Penulis memilih sampel 
jenuh untuk teknik samplingnya. Ciri-ciri subjek pada penelitian ini adalah berusia 5-6 tahun, tinggal di Kecamatan Gunungpati, dan status siswa aktif.

Tabel 1

Data Demografi Subjek Penelitian

\begin{tabular}{|c|c|c|c|}
\hline Nama & Usia & Jenis Kelamin & Agama \\
\hline $\mathrm{AF}$ & 5 Tahun 3 Bulan & Laki-laki & Islam \\
\hline $\mathrm{AB}$ & 6 Tahun & Perempuan & Islam \\
\hline AHL & 5 Tahun 7 Bulan & Laki-laki & Islam \\
\hline $\mathrm{AP}$ & 6 Tahun & Laki-laki & Islam \\
\hline $\mathrm{AAC}$ & 5 Tahun 1 Bulan & Perempuan & Islam \\
\hline $\mathrm{AG}$ & 5 Tahun 8 Bulan & Laki-laki & Islam \\
\hline APG & 5 Tahun 4 Bulan & Perempuan & Islam \\
\hline ATF & 5 Tahun 1 Bulan & Laki-laki & Islam \\
\hline BK & 5 Tahun 3 Bulan & Perempuan & Kristen \\
\hline BS & 5 Tahun 4 Bulan & Laki-laki & Islam \\
\hline BHL & 6 Tahun & Perempuan & Islam \\
\hline $\mathrm{BBN}$ & 5 Tahun 10 Bulan & Perempuan & Islam \\
\hline BP & 5 Tahun 7 Bulan & Laki-laki & Islam \\
\hline CY & 5 Tahun 1 Bulan & Laki-laki & Katholik \\
\hline CPK & 5 Tahun 4 Bulan & Laki-laki & Islam \\
\hline CL & 5 Tahun 9 Bulan & Perempuan & Islam \\
\hline CR & 5 Tahun 3 Bulan & Perempuan & Islam \\
\hline DZ & 5 Tahun & Laki-laki & Islam \\
\hline DPS & 5 Tahun 4 Bulan & Perempuan & Islam \\
\hline DRT & 5 Tahun 3 Bulan & Perempuan & Islam \\
\hline DW & 5 Tahun 7 Bulan & Perempuan & Kristen \\
\hline ESD & 5 Tahun 9 Bulan & Perempuan & Islam \\
\hline EP & 5 Tahun 3 Bulan & Laki-laki & Islam \\
\hline ELK & 5 Tahun 3 Bulan & Perempuan & Islam \\
\hline GD & 5 Tahun 7 Bulan & Laki-laki & Islam \\
\hline HP & 6 Tahun & Laki-laki & Islam \\
\hline HJD & 5 Tahun 8 Bulan & Laki-laki & Kristen \\
\hline HBM & 5 Tahun 2 Bulan & Perempuan & Islam \\
\hline HM & 5 Tahun 10 Bulan & Perempuan & Islam \\
\hline IJG & 5 Tahun 6 Bulan & Laki-laki & Islam \\
\hline $\mathrm{JK}$ & 5 Tahun 11 Bulan & Perempuan & Islam \\
\hline KGD & 5 Tahun 7 Bulan & Laki-laki & Islam \\
\hline $\mathrm{KB}$ & 5 Tahun 3 Bulan & Perempuan & Islam \\
\hline $\mathrm{LS}$ & 5 Tahun 4 Bulan & Perempuan & Islam \\
\hline MM & 5 Tahun 5 Bulan & Laki-laki & Islam \\
\hline MD & 5 Tahun 5 Bulan & Perempuan & Islam \\
\hline PDL & 5 Tahun 1 Bulan & Perempuan & Islam \\
\hline RSN & 5 Tahun 9 Bulan & Laki-laki & Islam \\
\hline RD & 5 Tahun 4 Bulan & Perempuan & Islam \\
\hline $\mathrm{ZM}$ & 5 Tahun & Perempuan & Islam \\
\hline ZLW & 5 Tahun 8 Bulan & Perempuan & Islam \\
\hline
\end{tabular}


Berdasarkan data demografi table, maka dapat dijelaskan bahwa partisipan berjumlah 41 anak, berusia antara 5-6 tahun, berjenis kelamin laki-laki sebesar 18 anak $(43,90 \%)$ dan perempuan 23 anak (56.10\%), serta beragama Islam 37 anak (90.24\%), Kristen 3 anak (7.32\%), dan Katholik 1 anak $(2.44 \%)$. Selama kegiatan penelitian, semua partisipan dapat berpartisipasi secara aktif. Desain eksperimen dalam penelitian ini adalah Intact Group Comparison.

\begin{tabular}{|l|l|}
\hline $\mathrm{X}$ & $\mathrm{O}_{1}$ \\
& $\mathrm{O}_{2}$ \\
\hline
\end{tabular}

Gambar 1. Desain Eksperimen Intact Group Comparison

Ket:

O1=Hasil pengukuran setengah kelompok yang diberikan perlakuan $(\mathrm{X})$.

$\mathrm{O} 2=$ Hasil pengukuran setengah kelompok yang tidak diberikan perlakuan (X).

Desain eksperimen ini menggunakan kelompok eksperimen (dikenakan perlakuan) dan kelompok kontrol (tidak dikenakan perlakuan) (Sudaryono, 2017). Model pembelajaran picture and picture berbasis keanekaragaman hayati adalah model pembelajaran aktif melalui penyajian gambar makhluk hidup (manusia, hewan, dan tumbuhan) dan dipasangkan atau diurutkan secara sistematis. Perlakuan dalam penelitian ini dengan mengurutkan gambar, menunjukkan gambar, memberikan informasi tentang gambar tersebut, dan menjelaskannya. Gambar yang dipakai adalah gambar keanekaragaman hayati. Perlakuan diberikan sebanyak 15 kali, yaitu seminggu 3 kali. Hal ini dimaksudkan agar anak dapat mengembangkan empati dalam kemasan keanekaragaman hayati. Empati anak usia dini adalah kemampuan anak di bawah 6 tahun untuk menangkap dan memaknai perasaan orang lain dengan berbagai masalahnya, berpikir dari pesepsi orang lain, serta menghargai berbagai jenis perasaan. Aspek empati terdiri dari empati kognitif (pengambilan perspektif dan imajinasi) dan empati afektif (perhatian empatik dan distress pribadi). Variabel dalam penelitian ini adalah empati anak usia dini sebagai variabel dependen dan model pembelajaran picture and picture berbasis keanekaragaman hayati sebagai variabel independen.

Metode pengumpulan data untuk mengetahui kemampuan empati anak di bawah 6 tahun dengan menggunakan Skala Empati AUD yang berjumlah 32 item. Skala Empati Anak Usia Dini merupakan skala yang disusun oleh penulis. Tinggi rendahnya empati dibuktikan dengan skor yang diperoleh. Semakin tinggi skor yang diperoleh berarti semakin tinggi empati anak usia dini, dan semakin rendah skor yang diperoleh berarti semakin rendah empati anak usia dini. Skala Empati Anak Usia Dini yang digunakan terbagi ke dalam empat alternatif jawaban, yaitu Sangat Sesuai (SS), Sesuai (S), Tidak Sesuai (TS), dan Sangat Tidak Sesuai (STS). Berdasarkan empat alternatif jawaban tersebut, maka pemberian skor pada item-item favourable bergerak dari 4-1 (dari SS sampai STS) dan untuk item-item unfavourable bergerak dari 1-4 (dari SS sampai STS). Penulis menggunakan Independent Samples t-Test untuk mengetahui perbedaan empati anak usia dini berdasarkan pada penerapan model pembelajaran picture and picture berbasis keanekaragaman hayati. Independent Samples t-Test merupakan uji statistik parametrik untuk mengukur perbedaan mean dua kelompok data yang independen.

Penulis berusaha menegakkan etika penelitian, dari perizinan sampai dengan berakhirnya penelitian. Selain perizinan kepada lembaga yang terkait, penulis juga melakukan perizinan kepada orangtua, mengingat partisipan masih berusia dini. Peneliti juga tidak mengambil gambar wajah partisipan, tetapi lebih kepada proses kegiatan eksperimennya. Hasil penelitian pun 
bersifat privasi, terutama yang menyangkut individu partisipan.

\section{HASIL DAN PEMBAHASAN}

Deskripsi statistik variabel penelitian pada Skala Empati AUD adalah sebagai berikut:

Tabel 2

Mean Empati AUD Berdasarkan Kelompok

\begin{tabular}{llccc}
\hline No. & Empati AUD & Mean & Min & Maks \\
\hline 1. & $\begin{array}{l}\text { Kelompok } \\
\text { Eksperimen }\end{array}$ & 87.81 & 55 & 119 \\
2. & $\begin{array}{l}\text { Kelompok } \\
\text { Kontrol }\end{array}$ & 73.80 & 50 & 112 \\
\hline
\end{tabular}

Selanjutnya dilakukan pengelompokan

pada Skala Empati AUD. Peneliti menggunakan kategorisasi sebagai berikut, rendah $(x=m+-1 S D)$, sedang $(m+-1 S D<$ $x=m+1 S D)$, dan tinggi ( $x>m+-1 S D)$. Kategori subjek digunakan untuk mengelompokkan skor dari Variabel Skala Empati AUD sebagai berikut:

Tabel 3

Kategorisasi Skor Empati AUD Kelompok Eksperimen $(\mathrm{N}=41)$

\begin{tabular}{lllcc}
\hline No. & \multicolumn{1}{c}{ Skor } & Kategori & Frekuensi & Persentase \\
\hline 1. & $\mathrm{x} \leq 63$ & Rendah & 5 & $23.81 \%$ \\
2. & $64<\mathrm{x}$ & Sedang & 6 & $28.57 \%$ \\
& $\leq 96$ & & & \\
3. & $\mathrm{x} \geq 97$ & Tinggi & 10 & $47.62 \%$ \\
\hline
\end{tabular}

Skor empati AUD yang diperoleh adalah 5 anak $(23.81 \%)$ berada dalam kategori rendah, 6 anak $(28.57 \%)$ berada dalam kategori sedang, dan 10 anak (47.62\%) berada dalam kategori tinggi. Apabila dilihat secara keseluruhan, dapat disimpulkan bahwa skor empati AUD kelas eksperimen yang diperoleh subjek penelitian berada dalam kategori tinggi.

Tabel 4

Kategorisasi Skor Empati AUD Kelompok Kontrol

\begin{tabular}{lllcc}
\hline No. & \multicolumn{1}{c}{ Skor } & Kategori & Frekuensi & Persentase \\
\hline 1. & $\mathrm{x} \leq 63$ & Rendah & 7 & $35 \%$ \\
2. & $64<\mathrm{x}$ & Sedang & 11 & $55 \%$ \\
& $\leq 96$ & & & \\
3. & $\mathrm{x} \geq 97$ & Tinggi & 2 & $10 \%$ \\
\hline
\end{tabular}

Skor empati AUD yang diperoleh adalah 7 anak (35\%) berada dalam kategori rendah, 11 anak (55\%) berada dalam kategori sedang, dan 2 anak (10 \%) berada dalam kategori tinggi. Apabila dilihat secara keseluruhan, maka dapat disimpulkan bahwa skor empati AUD kelas kontrol yang diperoleh subjek penelitian berada dalam kategori sedang.

Langkah selanjutnya adalah melakukan analisis data untuk menjawab hipotesis penelitian, yaitu Independent Sample t-Test dengan menggunakan software pengolah data statistik. Sebelumnya dilakukan uji normalitas dan uji homogenitas. Uji asumsi normalitas menggunakan Kolmogrov-

Smirnov.

Tabel 5

Uji Normalitas Data Penelitian

\begin{tabular}{|c|c|c|c|c|}
\hline \multicolumn{5}{|c|}{ Variabel } \\
\hline No & $\begin{array}{l}\text { Empati } \\
\text { AUD }\end{array}$ & $\begin{array}{c}\text { Koef. } \\
\text { Normalitas }\end{array}$ & $\mathrm{P}$ & Ket. \\
\hline 1. & $\begin{array}{l}\text { Kelompok } \\
\text { Eksperimen }\end{array}$ & 0.153 & 0.200 & Normal \\
\hline 2. & $\begin{array}{l}\text { Kelompok } \\
\text { Kontrol }\end{array}$ & 0.152 & 0.200 & Normal \\
\hline
\end{tabular}

Uji normalitas di atas menghasilkan nilai $\mathrm{Z}$ sebesar 0.153 dengan $\mathrm{p}>0.05$ untuk kelompok eksperimen dan 0.152 dengan $\mathrm{p}>$ 0.05 untuk kelompok kontrol. Berdasarkan hasil tersebut, maka dapat dikatakan bahwa sebaran skor data tersebut normal.

Tabel 6

Uji Homogenitas Data Penelitian

\begin{tabular}{llccc}
\hline & & Koef. F & & \\
No. & Variabel & Lavene & P & Ket. \\
\hline 1. & Empati & 2.797 & 0.102 & Homogen \\
& AUD & & & \\
\hline
\end{tabular}

Uji homogenitas di atas menghasilkan nilai $\mathrm{F}$ Lavene sebesar 0.656 dengan $\mathrm{p}>0,05$. Berdasarkan hasil tersebut, maka dapat dikatakan bahwa varian dari dua atau lebih kelompok data adalah sama.

Hasil uji normalitas dan homogenitas menunjukkan bahwa data yang terkumpul memenuhi syarat untuk analisis selanjutnya, 
yaitu menggunakan Independent Sample tTest. Hasil pengujian hipotesis dalam penelitian ini sebagai berikut:

Tabel 7

Uji Beda Data Penelitian

\begin{tabular}{llccl}
\hline No. & Variabel & T & P & \multicolumn{1}{c}{ Ket } \\
\hline 1. & Empati & 2.310 & 0.026 & Terdapat \\
& AUD & & & Perbedaan \\
\hline
\end{tabular}

Uji hipotesis di atas menghasilkan nilai $\mathrm{t}$ sebesar 2.310 dengan $\mathrm{p}<0,05$. Berdasarkan hasil tersebut, maka dapat dikatakan bahwa terdapat perbedaan yang signifikan empati anak usia dini ditinjau dari penerapan model pembelajaran picture and picture berbasis keanekaragaman hayati. Empati anak usia dini pada kelompok eksperimen lebih tinggi daripada kelompok kontrol. Hipotesis dalam penelitian ini diterima.

Sejalan dengan pendapat (Iis, 2012), empati merupakan kemampuan untuk menangkap dan memaknai perasaan orang lain dengan berbagai masalahnya, berpikir dari pesepsi orang lain, serta menghargai berbagai jenis perasaan. Ketika anak memunculkan empati dalam dirinya, berarti anak mulai mampu memposisikan perasaannya pada perasaan orang lain. Kemampuan empati tidak dengan sendirinya dimiliki oleh anak, tetapi empati merupakan suatu kemampuan yang harus dibentuk oleh lingkungan. Hal ini menjadi tugas orang dewasa yang berada di sekitar anak. Penelitian dilakukan pada orangtua dalam menstimulasi anak dengan memberikan training tentang tumbuh kembang anak (Tarnoto, Tentama, \& Pranungsari, 2017). Hasilnya orangtua yang mendapatkan training tentang tumbuh kembang mempunyai kemampuan lebih dalam melakukan stimulasi anak. Berbeda dengan penelitian Tarnoto, Tentama, dan Pranungsari yang menggunakan perlakuan training tumbuh kembang pada orangtua, penelitian ini menggunakan model pembelajaran yang langsung diberikan pada anak. Anak secara langsung memahami makna empati melalui penyajian gambar bertema yang memuat pesan empati. Pesan tersebut akan dimaknai dan tersimpan untuk pemecahan masalah di kemudian hari.

Bukan hanya orangtua, lingkungan sekitar juga turut bertanggung jawab terhadap tumbuh kembang anak, termasuk guru. (Widyasari \& Zainuddin, 2018) menambahkan bahwa usia 5-7 tahun merupakan usia kritis. Guru harus memiliki persepsi yang tepat untuk perkembangan emosinya dan memberikan stimulasi yang tepat. Guru dipandang sebagai individu yang mampu memberikan pengaruh luar biasa pada anak. Berbagai model dapat guru pilih sebagai upaya mendapatkan perkembangan emosi anak yang optimal, termasuk empati. Penulis menerapkan model pembelajaran picture and picture berbasis keanekaragaman hayati untuk mengasah kemampuan empati anak usia dini. Kegemaran anak pada binatang maupun tumbuhan dapat digunakan untuk menstimulasi perkembangannya. Gambar cerita dapat membentuk konsep lingkungan yang sesungguhnya. Anak akan dibawa kepada pemahaman kondisi yang sesungguhnya (Gonen \& Guler, 2011).

Aspek empati terdiri dari empati kognitif (pengambilan perspektif dan imajinasi) dan empati afektif (perhatian empatik dan distress pribadi) (Zoll \& Enz, 2012). Sepakat jika cerita bergambar dapat meningkatkan empati, imajinasi, kejujuran, solidaritas, dan mengatasi stress (Cengiz \& Duran, 2017). Anak mampu mengembangan perilaku empati dengan meniru perilaku tokoh dalam cerita. Hal ini membuktikan bahwa keberadaan tokoh dan keteladanannya sangat diperlukan untuk mendampingi anak dalam mencapai kemampuan empati. Seluruh aspek ini dapat dikemas secara utuh dalam tampilan gambar yang memiliki tema dan pesan yang tersampaikan. 
Pembelajaran dapat dilaksanakan dengan cara bekerja sama (Huda, 2011). Picture and picture adalah model pembelajaran kerjasama aktif yang menggunakan gambar berpasangan atau urutan sistematis, seperti urutan gambar, menunjukkan gambar, informasi gambar, dan menjelaskannya. Gambar yang dipakai dapat berupa keanekaragaman hayati. Hal ini dimaksudkan agar anak dapat mengembangkan empati dalam kemasan keanekaragaman hayati. Cinta terhadap lingkungan juga harus ditumbuhkan sejak dini. Anak berjenis kelamin perempuan lebih dominan memiliki kepedulian terhadap lingkungan daripada anak laki-laki, diperlukan upaya lebih untuk membuat anak laki-laki peduli pada lingkungan (Akyol, Sali, \& Korukcu, 2011).

Perbedaan kemampuan empati anak usia dini dapat dilihat dari mean, mean empati kelas eksperimen adalah 87.81 dan kelompok kontrol 73.80. Empati kelompok eksperimen memiliki mean lebih tinggi daripada empati kelompok kontrol. Penerapan model pembelajaran picture and picture berbasis keanekaragaman hayati efektif untuk mendapatkan kemampuan empati anak usia dini secara optimal. Kelebihan penelitian ini adalah model pembelajaran yang sangat menyenangkan, sehingga mengundang ketertarikan anak, yaitu model pembelajaran picture and picture berbasis keanekaragaman hayati. Pesan yang disampaikan lewat gambar akan sampai kepada anak. Penelitian ini juga memiliki keterbatasan, mengingat partisipan adalah anak usia dini, maka perlakuan tidak semudah yang dibayangkan. Penulis harus mengondisikan anak semaksimal mungkin, masih terdapat beberapa anak yang asyik bermain sendiri, meskipun akhirnya semua anak berhasil menyelesaikan tugas dengan tuntas.

\section{SIMPULAN}

Pada penelitian ini terdapat perbedaan empati anak usia dini ditinjau dari penerapan model pembelajaran picture and picture berbasis keanekaragaman hayati. Kemampuan empati anak usia dini pada kelompok eksperimen lebih tinggi daripada kelompok kontrol. Model pembelajaran ini juga mengangkat binatang dan tumbuhan sebagai objek stimulasi. Selain manusia, binatang dan tumbuhan merupakan objek yang sangat digemari oleh anak, sehingga mempermudah masuknya pesan yang disampaikan dalam cerita bergambar tersebut. Model pembelajaran picture and picture berbasis keanekaragaman hayati secara nyata dapat membuat kemampuan empati anak usia dini sesuai dengan yang diharapkan. Kemampuan empati yang terbentuk sejak dini akan menetap dan dikembangkan sampai usia dewasa nanti. Saran penulis bagi guru dan orangtua diharapkan dapat memberikan model, kesempatan dan pendampingan pada anak untuk mengembangkan kemampuan empati, serta bagi penulis selanjutnya untuk dapat memodifikasi model pembelajaran ini dalam rangka meningkatkan empati anak usia dini.

\section{DAFTAR PUSTAKA}

Akyol, A. K., Sali, G., \& Korukcu, O. (2011). Children's Emphatic Tendencies with Respect to Their Gender and Grade Level. The 2011 Barcelona European Academic Conference, (pp. 10451051). Barcelona.

Altay, F. B., \& Gure, A. (2012). Relationship among the Parenting Styles and the Social Competence and Prosocial Behaviors of the Children Who are Attending to State and Private Preschools. Educational Sciences: Theory \& Practice, 2712-2718.

Astuti, H. P. (2013). Perkembangan Anak Usia Dini 1. Yogyakarta: Deepublish. 
Cengiz, S., \& Duran, E. (2017). Analysis of Values on Preschool Period Children Story and Tale Books. Education and Science, 42(191), 205-233, doi: 10.15390/EB.2017.6945.

Gonen, M., \& Guler, T. (2011). The Environment and Its Place in Children's Picture Story Books. Procedia Social and Behavioral Sciences, 3633-3639, doi: 10.1016/j.sbspro.2011.04.347.

Huda, M. (2011). Cooperative Learning Metode, Teknik, Struktur, dan Model Penerapan. Yogyakarta: Pustaka Pelajar.

Iis, N. (2012). Pengembangan Empati Anak Usia Dini melalui Mendongeng di Taman Kanak-kanak Asyiyah Pariaman. Pesona PAUD, 1(1), 1-11.

Peraturan Menteri Pendidikan dan Kebudayaan RI. (2014). Peraturan Menteri Pendidikan dan Kebudayaan RI No. 37 Tahun 2014 Tentang Standar Nasional Pendidikan Anak Usia Dini. Jakarta: Kemendikbud.

Sudaryono. (2017). Metode Penelitian. Jakarta: Rajawali Pers.
Tarnoto, N., Tentama, F., \& Pranungsari, D. (2017). Intervention Model of Children Growth and Development to Improve Stimulation Skills of Parent with Early Child. 3rd Asean Conference on Psychology, Counseling and Humanities (AC-PCH 2017) (pp. 218-222). Malang: Atlantis Press.

Widyasari, C., \& Zainuddin, A. (2018). Emotion Development Stimulation Method in Children 5-7 Years Old. The 3rd Progressive and Fun Education (pp. 79-83). Surabaya: Asosiasi LPTK Perguruan Tinggi Muhammadiyah (ALPTK-PTM).

Yamahashi, C., Yamaguchi, E., Inagaki, S., Okuyama, H., Tajima, J., Akiko, H., . Bando, G. (2015). Supporting Zoo Visitors' Scientific Observations through the Picture-story Show. Procedia-Social and Behavioral Sciences, $\quad 85-90, \quad$ doi: 10.1016/j.sbspro.2014.12.647.

Zoll, C., \& Enz, S. (2012). A Questionnaire to Assess Affective and Cognitive Empathy in Children. Bamberg: OPUS Publications Server. 